\title{
Effectiveness of an empowerment-based educational program in self-efficacy perception in patients with diabetes
}

Eficácia de um programa educacional baseado no empowerment na perceção de autoeficácia em utentes com diabetes

Eficacia de un programa educativo basado en el empoderamiento en la percepción de la autoeficacia en pacientes con diabetes

Matilde Almeida*iD; Maria Rui Miranda Grilo Correia de Sousa** ID;

Helena Maria Almeida Macedo Loureiro*** iD

\section{Abstract}

Background: Studies suggest that empowerment-based educational models, implemented in patients with diabetes, may encourage the improvement of perceived self-efficacy. This variable is considered relevant in the therapeutic regimen self-management.

Objectives: To evaluate the effectiveness of an empowerment-based educational program in patients with type 2 diabetes mellitus.

Methodology: A quasi-experimental study, with two different evaluation moments, with a 6-week interval. A randomized sample of 42 participants (experimental group $=19$; control group $=23$ ), registered in a family health unit of the ARS of Central Portugal. The Diabetes Empowerment Scale - Short Form (DES-SF) was the instrument chosen to determine the program's effectiveness. All formal and ethical procedures were assured.

Results: Patients subjected to the empowerment-based educational program presented a higher self-efficacy perception $(p=0.000)$ than those who followed the regular surveillance protocol.

Conclusion: Empowerment-based educational programs seem to contribute to an improvement in perceived self-efficacy and should, therefore, be used as an educational strategy for patients with type 2 diabetes mellitus.

Keywords: self efficacy; diabetes mellitus, type 2; health education; empowerment for health; nursing; educational program

\section{Resumo}

Enquadramento: Estudos sugerem que modelos educativos baseados no empowerment, implementados em pessoas com diabetes, poderão fomentar a melhoria da autoeficácia percecionada. Esta variável é considerada relevante na autogestão do regime terapêutico.

Objetivos: Avaliar a eficácia de um programa educacional baseado no empowerment, na perceção de autoeficácia, em utentes com diabetes mellitus tipo 2.

Metodologia: Estudo quasi-experimental, com avaliação antes e após implementaçáo do programa, com intervalo de 6 semanas. Amostra aleatória randomizada, constituída por 42 participantes (grupo experimental = 19; grupo de controlo $=23$ ), inscritos numa unidade de saúde familiar da Administração Regional de Saúde do Centro. O Diabetes Empowerment Scale - Short Form (DES-SF) foi o instrumento utilizado para determinar a eficácia do programa. Foram assegurados todos os procedimentos formais e éticos.

Resultados: Os utentes submetidos a um programa educativo baseado no empowerment apresentaram uma maior perceçáo de autoeficácia $(p=0,000)$, comparativamente com aqueles que seguiram o regular protocolo de vigilância.

Conclusáo: Os programas educacionais baseados no $\mathrm{em}$ powerment parecem contribuir para uma melhoria da autoeficácia percebida, pelo que poderáo ser assumidos como estratégias a aplicar a utentes com diabetes mellitus tipo 2.

Palavras-chave: autoeficácia; diabetes mellitus tipo 2; educação para a saúde; empoderamento para a saúde; enfermagem; programa educacional

*MSc., RN, Clínica da Glória - Cuidados de Saúde Lda., 3810-151, Aveiro, Portugal [matildealmeidacarlos@gmail.com]. (D https://orcid.org/0000-0001-9986-4498. Contribution to the article: bibliographical research; data collection; statistical treatment and analysis; data analysis and discussion; writing of the article. Address for correspondence: Rua 31 de Janeiro, $n^{0}$ 19, r/c, fracção I/J, 3810-155, Aveiro, Portugal.

**Ph.D., Adjunct Professor, Nursing School of Porto, 4200-072, Porto, Portugal. Researcher. [mariarui@esenf.pt]. (1) https://orcid.org/0000-0002-6669-8339. Contribution to the article: research advisor; conception of the intervention program; writing of the article.

***:Ph.D., Adjunct Professor, School of Health of the University of Aveiro, 3810-193, Aveiro,

Portugal [hloureiro@ua.pt]. (D) https://orcid.org/0000-0003-1826-5923. Contribution to

the article: research co-advisor; methodological design; writing of the article.

\section{Resumen}

Marco contextual: Los estudios sugieren que los modelos educativos basados en el empoderamiento, implementados en personas con diabetes, pueden fomentar la mejora de la autoeficacia percibida. Esta variable se considera relevante en el autocontrol del régimen terapéutico.

Objetivos: Evaluar la eficacia de un programa educativo basado en el empoderamiento y la percepción de la autoeficacia en pacientes con diabetes mellitus tipo 2 .

Metodología: Estudio cuasiexperimental, con evaluación antes y después de la implementación del programa, con un intervalo de 6 semanas. Muestra aleatoria, compuesta por 42 participantes (grupo experimental $=19$; grupo de control $=23$ ), inscritos en una unidad de salud familiar de la Administración Regional de Salud del Centro. La Diabetes Empowerment Scale - Short Form (DES-SF) fue el instrumento utilizado para determinar la efectividad del programa. Se garantizaron todos los procedimientos formales y éticos.

Resultados: Los pacientes que se sometieron a un programa educativo basado en el empoderamiento tuvieron una mayor percepción de la autoeficacia $(p=0,000)$ en comparación con los que siguieron el protocolo de vigilancia regular.

Conclusión: Los programas educativos basados en el empoderamiento parecen contribuir a mejorar la autoeficacia percibida, por lo que pueden asumirse como estrategias para aplicar a los pacientes con diabetes mellitus tipo 2 .

Palavras clave: autoeficacia; diabetes mellitus tipo 2; educación para la salud; empoderamiento para la salud; enfermería; programa educativo 


\section{Introduction}

The estimated incidence of type 2 diabetes mellitus (DM) in the Portuguese population has increased, reaching in 2015 values of $13.3 \%$ in people between 20 and 79 years old, which means that more than one million Portuguese individuals in this age range had this disease (Direção-Geral da Saúde, 2017). The treatment of DM does not imply its cure, but a correct and complex self-management of its therapeutic regimen, thus minimizing or preventing the onset of long-term complications. Therefore, the primary goal of treatment is to control blood glucose levels within the desired values, which contributes to the maintenance of the quality of life, preventing and/or minimizing the risk to develop late complications (Associação Protetora dos Diabéticos de Portugal, 2017). Health education (HE) should be person-centered to promote knowledge and skills necessary to the self-management of the disease, as well as to incorporate the person's needs, goals, values, and life experiences (American Diabetes Association, 2017). HE aims to support the person in decision-making, problem-solving, and self-care behaviors (American Diabetes Association, 2017). Literature refers to self-efficacy perceptions within this context as being one of the variables that most predict these behaviors. Traditional educational programs which favor the conveyance of information about the disease and its treatment do not appear to have as much impact as those which, with empowerment as their underlying philosophy, focus on the person and his/her skills to follow the goals he/she defined for his/her health (Anderson \& Funnell, 2005). Consequently, there is an urgent need to abandon the traditional model of HE, mainly focused on the disease and prescription of behaviors, and to adopt a person-centered model for the promotion of his/her empowerment (Anderson \& Funnell, 2005).

Although some programs targeted to people with DM are developed in Portugal, these are little disseminated and are not apparently based on previously tested conceptual models, also lacking a rigorous evaluation of their impact. In 2015, an empowerment-based intervention program was developed, called Living Harmoniously with Diabetes, and presented satisfactory results in several psychosocial, be- havioral, and clinical variables, particularly in self-efficacy perceptions and self-care behaviors. However, these authors focused on nurse involvement in clinical practice, particularly in the search for new ways of supporting the person with diabetes to integrate and manage his/her illness, on the analysis of factors that influence self-care behaviors, as well as on the design of this program (Sousa et al., 2017). Two evaluations were conducted before and after its implementation, but without a control group and random sample (Sousa et al., 2017). Considering the abovementioned scenario of knowledge, the authors considered it pertinent to conduct this quasi-experimental study to assess the effectiveness of the Living Harmoniously with Diabetes program in self-efficacy perceptions in patients with type $2 \mathrm{DM}$.

\section{Background}

Intervention within the scope of DM is one of the most significant health intervention emergencies of the $21^{\text {st }}$ century, depending on the epidemiological situation it manifests in contemporary societies. Data report that, currently, circa 424.9 million adults worldwide suffer from DM (International Diabetes Federation, 2017). It is considered as one of the diseases in Portugal that most require a strategic intervention due to, among other factors, its magnitude and degree of severity of disability, but also possible self-control.

To control the disease, the person should have a central role in his/her care plan and be an active element in his/her treatment (International Diabetes Federation, 2017). DM self-care is regarded as an ongoing process of developing knowledge and skills that allow a person to be able to learn to live with the pathology's complex nature in his/her social context. The role of self-care in DM is of extreme importance because the daily primary care is provided by the patients themselves and/or their families (International Diabetes Federation, 2017).

Self-care therapeutic education has been considered essential so that people can achieve the desired results and adopt behaviors that promote a healthy adaptation to diabetes with quality of life (Menino, Dixe, \& Louro, 2016). Therefore, $\mathrm{HE}$ is one of the pillars of type $2 \mathrm{DM}$ 
treatment and should not restrict itself to an exchange of information. The health care professional should plan a suitable program taking into account the health needs and characteristics of each person, family, and community (Brunton \& Polonsky, 2017).

It is crucial that interventions developed by nurses in this area be monitored from a quality perspective because only thus it will be possible to delineate a care plan based on the available evidence (Menino et al., 2016). These interventions should also be directed at the variables that affect people's behavior.

The health beliefs are one of the main focal points to address in disease self-management programs in patients with DM. According to Saad et al. (2017), self-efficacy beliefs directly influence therapeutic adherence because a greater self-efficacy perception is associated with a higher incidence of self-care behaviors. Bandura (1989) defines self-efficacy as the belief that a person can perform the desired behavior successfully to produce the desired results, and is capable of controlling his/her motivation, thought processes, and behavior patterns. The concept of psychosocial self-efficacy implies the will and ability of people to engage in various behavioral changes at the level of disease prevention and management, encompassing several dimensions like the management of diabetes' psychosocial aspects, the dissatisfaction with treatment, the readiness to change and to establish and achieve diabetes-related goals.

The use of empowerment as an HE approach intends, besides conveying knowledge, to reinforce the appropriate attitudes in the person and build an ongoing process of motivation and involvement, promoting an exchange of knowledge, power, and responsibilities between the patient and the health professional, possibly leading to improved self-efficacy (Anderson $\&$ Funnell, 2005). The various studies refer that diabetes self-management empowerment-based programs are more effective than the traditional educational approach (Chen, Wang, Lin, Hsu, \& Chen, 2015; Cortez et al., 2017; Funnell, Tang, \& Anderson, 2007; Sousa et al., 2017). They focus on each person's specific needs, a comprehensive perspective which comprises all the determinants that affect the well-being of individuals (Cortez et al., 2017; Funnell et al., 2007). In addition, healthcare delivery should not be limited to relieving an ailment; it should, instead, be directed at educating and empowering the patient, so as to improve his/her ability to self-manage his/her health status and self-efficacy perceptions (Cortez et al., 2017; Ratner, Davis, Lhorka, Wille, \& Walls, 2017; Chen et al., 2015).

For that reason, it is necessary to work in tandem with the patient to empower him/her, providing him/her tools to manage his/her regimen, promoting his/her autonomy, effectiveness and, decision-making skills. Hence, the traditional model should be replaced for a person-centered model, compatible with an empowerment-based approach (Funnell et al., 2007).

As a result, Anderson and Funnell (2005) propose an empowerment-based model to support behavior change, built together with the patient, which incorporates five phases: 1. - Identifying the problem; 2. - Exploring feelings associated with the problem; 3. - Establishing goals; 4. - Developing a plan; 5. - Evaluating the results of the implementation of the plan.

\section{Research question}

How efficient is an empowerment-based educational program in self-efficacy perceptions in patients with type $2 \mathrm{DM}$, who monitor their health in a family health team?

\section{Research hypothesis}

When submitted to an empowerment-based health education program, people with type 2 DM have a higher self-efficacy perception than those who are not subjected to this program.

\section{Methodology}

This quantitative and quasi-experimental study follows a positivist and empirical-analytical model. It includes a control group and two evaluation moments.

Developed in a family health unit (USF), of the Health Center Cluster (Agrupamento de Centros - ACES) of Baixo Vouga, part of the Regional Health Administration (Administração Regional de Saúde-ARS) of Central Portugal, this study 
considered a target population including all patients diagnosed with type 2 diabetes mellitus, registered, and carrying out their health surveillance in the selected health care unit. The probabilistic sampling method (Figure 1) was used, according to the variables age, gender, and time since diagnosis for randomization between the experimental group and control group. As for the inclusion criteria, participants should be 18 years old or more, willing to participate in the study, diagnosed with diabetes for more than a year, and possess skills to manage their disease autonomously. The exclusion criteria included not accepting to participate in all sessions of the program, concerning the experimental group, and the unavailability to fill out the initial and final evaluation questionnaire in both groups.

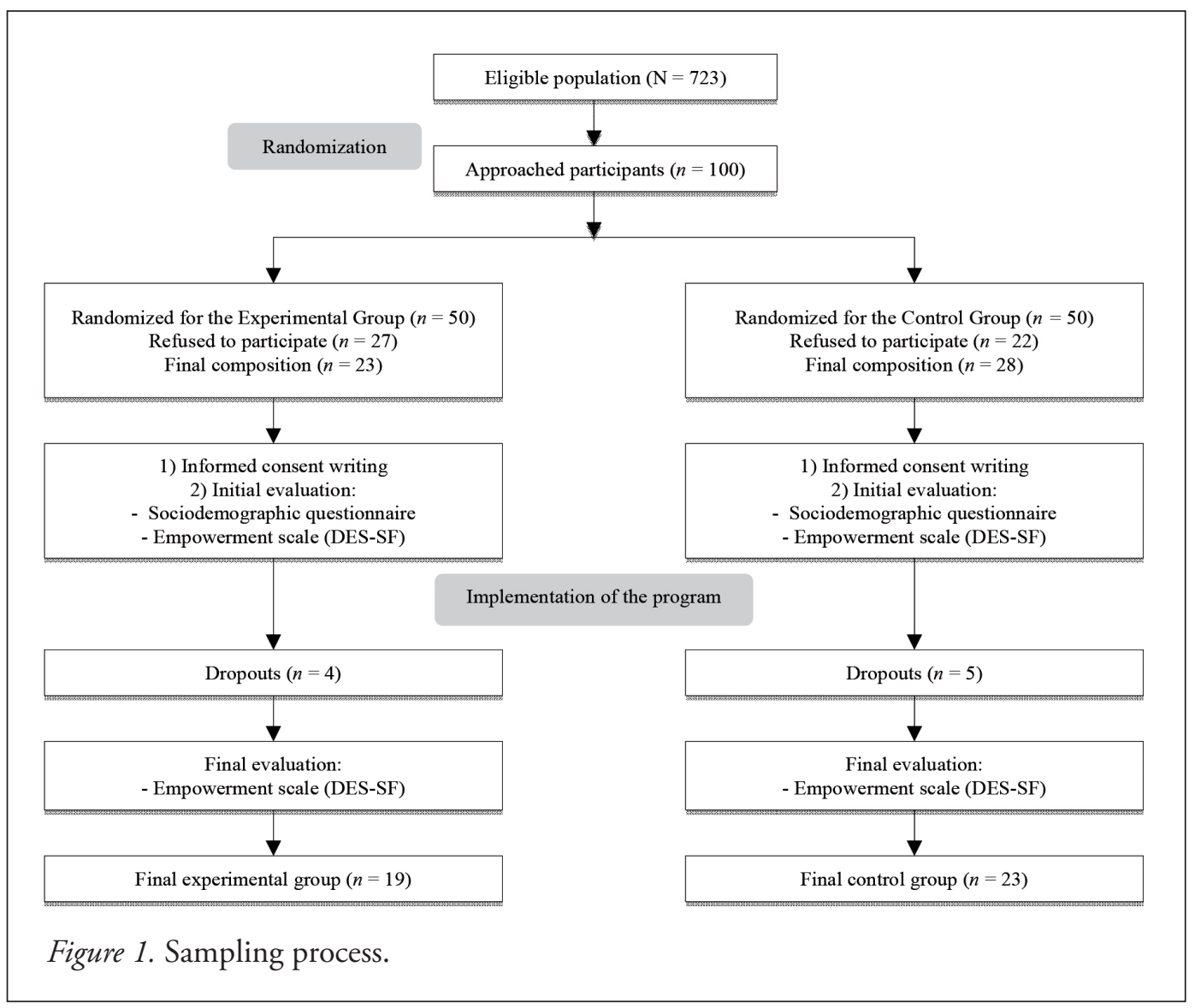

The implemented program, named Living Harmoniously with Diabetes (Sousa et al., 2017), was inspired by the empowerment philosophy, more specifically by the behavioral change model of Anderson and Funnell (2005).

This study was implemented in six two-hour group sessions held once a week. Each intervention group was composed of six to eight participants. This program used an interactive and practical approach, aiming to work with the participants on decision-making and daily problem-solving skills. Like in the study by Sousa et al. (2017), the content of the educational program was grouped into 4 modules: Module 1 (what diabetes means to me); Module 2 (how diabetes affects my daily life); Module 3 (which are my diabetes-related goals); Module 4 (how can I manage my diabetes through diet, physical exercise, medication, and self-surveillance).

The Diabetes Empowerment Scale - Short Form (DES-SF; Anderson, Fitzgerald, Gruppen, \& Funnell, 2003) was the chosen instrument to determine the effectiveness of the program, applied to the participants by hetero-evaluation in two 
distinct moments, before the program (M0) and after the program (M1), with a 6-week interval. The DES-SF was translated and adapted to the Portuguese context by Sousa et al. (2017), with the name Escala do Empowerment na Diabetes. Composed of eight statement-like items, it allows assessing the psychosocial self-efficacy and intends to measure: 1) the ability to manage the psychosocial aspects of diabetes; 2) the dissatisfaction with treatment and readiness for change; 3) the ability to delineate and achieve diabetes-related goals. The participants could give their answers on a Likert-type scale that varies between 1 (I completely disagree) and 5 (I agree completely). The result is obtained by averaging the sum of all items, in which higher values suggest a greater perception of psychosocial self-efficacy. In determining the homogeneity of its items, the Cronbach alpha values of 0.82 were identified, before the implementation of the educational program, signifying a good internal consistency of the instrument and overlapping with previous studies (Sousa et al., 2017).

The sociodemographic and clinical questionnaire was composed of closed-ended questions that allowed characterizing the variables age, sex, marital status, level of education, and professional situation, as well as evaluating the history of diabetes, such as the age at diagnosis and the time since diagnosis.

The practical intervention was preceded by a set of formal and ethical procedures. The research project was submitted to the Ethics Committee for Health of the ARS of Central Portugal and obtained a favorable opinion (no. 16/2017) and authorization from the coordinator of the USF of ACES Baixo Vouga, where the intervention has been implemented. Likewise, a request was made to the authors of the Living Harmoniously with Diabetes educational program for authorization to reproduce and apply it, and authorization was also requested to the authors of the used scales. The study complied with the regulatory norms for research laid out in the Declaration of Helsinki and the existing national legislation regarding the European Code of Conduct for Research Integrity (All European Academics, 2018) and the General Data Protection Regulation (Regulamento n. ${ }^{\circ} 798 / 2018,2018$ ). The confidentiality of the collected information was ensured through coded questionnaires, and it was ensured that any information provided by the participants to researchers would not be accessible to elements outside of the research team and health team, to respect the principles of research ethics. After the nature, duration, objectives, method, disadvantages, and risks of the study were explained to the sample elements, they were asked to participate in the study. Thus, informed and free consent was assured.

The data collected were processed and treated through the IBM SPSS statistical program, version 24.0, keeping them preserved according to the data protection and open science norms. The Wilcoxon and Mann-Whitney statistical inference tests were used because the assumed normality of the variables was not confirmed.

\section{Results}

The experimental group comprised 10 women $(52.6 \%)$ and 9 men $(47.4 \%)$, with a mean age of 71 years $(S D=6.8 ; M n=59 ; M x=87)$. Concerning academic qualifications, the participants had a low level of education. Most had completed only primary school $(n=14 ; 73.6 \%)$, four had completed the ninth grade $(21.1 \%)$, and only one participant had attended secondary school (5.3\%). In terms of employment, the majority was already inactive, due to retirement or invalidity $(n=17 ; 89.5 \%)$.

The control group was composed of 10 women (43.5\%) and 13 men (56.5\%), with a mean age of 67 years $(S D=10.45 ; M n=44 ; M x=84)$. As to the academic qualifications, it was also noted that the population had a low level of education, as the most had completed only primary school $(n=13 ; 56.5 \%)$, two had attended the ninth grade $(8.7 \%)$, and five had attended secondary school $(21.7 \%)$. The remainder had a bacharelato (4.3\%). Only two participants provided no answer to this question. In terms of employment, the majority was already inactive, due to retirement or invalidity $(n=18 ; 78.3 \%)$. Statistical tests were performed to assess the homogeneity of the groups regarding the variables age, gender, and academic qualifications. The homogeneity of the groups relating to these variables was verified (Table 1 ). 
Table 1

Homogeneity of the sociodemographic variables between the experimental group and the control group

\begin{tabular}{lc}
\hline Variable & Sig. $(\boldsymbol{p})$ \\
\hline Age & $3.09(0.86) \dagger$ \\
Gender & $0.35(0.55)^{*}$ \\
Academic qualifications & $4.13(0.29)^{*}$ \\
\hline
\end{tabular}

Note. $\dagger$ Levene's test; ${ }^{*}$ Chi-squared test.

In the experimental group, the mean age at diagnosis of type $2 \mathrm{DM}$ was 56 years $(S D=$ 9.68). The mean duration of the disease was 15 years $(S D=11.67)$. As to the control group, the mean age at diagnosis of type $2 \mathrm{DM}$ was 55 years $(S D=10.18)$, and the mean duration of the disease was 13 years $(S D=11.14)$.

In the intragroup evaluation, there was an out- standing improvement of their self-efficacy perception in the experimental group, with statistically significant results (Table 2 ). On the other hand, the values decreased in what concerns the self-efficacy perception in the control group, but without statistically significant differences.

Table 2

Intra-group evaluation of self-efficacy before and after the implementation of the program in the experimental group and the control group

\begin{tabular}{lccc}
\hline Group & $\boldsymbol{M}(\boldsymbol{S D})$ & $\boldsymbol{M}(\boldsymbol{S D})$ & $\boldsymbol{Z}(\boldsymbol{p})$ \\
\hline Experimental Group $(n=19)$ & M0 & M1 & $-2.875(0.04)$ \\
Control Group $(n=23)$ & $4.45(0.99)$ & $4.40(0.80)$ & $-0.765(0.44)$ \\
\hline
\end{tabular}

Note. $\mathrm{M} 0=$ Initial moment, before the program; M1 = Final moment, after the program; $M=$ Mean; $S D=$ Standard deviation; $Z=$ Wilcoxon test; $p=$ Significance test.

In the final moment, as a way to answer the research question, it was assessed if there were differences in self-efficacy perception between the experimental group and the control group. In fact, there were statistically significant differences, meaning that the self-efficacy perception increased in participants who have joined the program. These results confirm the research hypothesis initially formulated, emphasizing that the empowerment-based intervention has led to an improved self-efficacy perception in people with type $2 \mathrm{DM}$ (Table 3 ).

Table 3

Intergroup evaluation of self-efficacy before and after the implementation of the program in the experimental group and the control group

\begin{tabular}{lccc}
\hline $\begin{array}{l}\text { Evaluation } \\
\text { moment }\end{array}$ & $\begin{array}{c}\text { Experimental Group } \\
\boldsymbol{M}(\boldsymbol{S D})\end{array}$ & $\begin{array}{c}\text { Control Group } \\
\boldsymbol{M}(\boldsymbol{S D})\end{array}$ & $\boldsymbol{U}(\boldsymbol{p})$ \\
\hline M0 & $3.45(0.99)$ & $4.02(0.95)$ & $112.50(0.007)$ \\
\hline M1 & $4.40(0.80)$ & $3.79(0.49)$ & $109.00(0.005)$ \\
\hline
\end{tabular}

Note. $\mathrm{M} 0=$ Initial moment, before the program; M1 = Final moment, after the program; $M=$ Mean; $S D=$ Standard deviation; $U=$ Mann-Whitney test; $p=$ Significance test. 
Also, the results of this table show that, before the intervention, the control group had a better self-efficacy perception than the experimental group, with statistically significant results.

\section{Discussion}

The sample shows sociodemographic characteristics similar to those observed in other studies, developed with people diagnosed with type 2 DM. The mean age of the sample was 77 years, a fact reflected in the Annual Report of the National Observatory of Diabetes (Observatório da Diabetes, 2016), because this disease predominantly prevails in more advanced stages of life. Regarding the level of education, most sample elements only attended primary school. This finding is transverse to other studies in populations with the same age and the same diagnosis (Aveiro, Santiago, Pereira, \& Simóes, 2015; Sousa et al., 2017).

There was an improvement in their self-efficacy perceptions in the experimental group, presenting statistically significant results, which could impact the therapeutic regimen management significantly (Chen et al., 2015; Cortez et al., 2017; Funnell et al., 2007; Saad et al., 2017; Sousa et al., 2017). This leads to the belief that the participants of the educational program obtained a higher psychosocial self-efficacy perception than those who did not participate. On the other hand, there were no statistically significant differences throughout the study regarding the self-efficacy perceptions in the control group, despite a decrease in its value. Similar results were observed in studies developed by Chen et al. (2015), Cortez et al., (2017), Funnell et al. (2007), and Sousa et al. (2017), which also obtained higher self-efficacy perception values after the implementation of an empowerment-based educational program, suggesting an increase in perceived self-efficacy. Chen et al. (2015) applied an empowerment-based educational program, similar to the previously presented, in patients with type $2 \mathrm{DM}$, in Taiwan. The authors concluded that the empowerment-based intervention encourages participants to find their coping strategies, goals, and purposes, and qualifies them for correct self-care management. The results of this study were reassessed after 3 months, noting that the same levels of care and effectiveness were maintained, which proves the effectiveness of empowerment-based educational programs. In 2017, Cortez and collaborators also implemented, in Brazil, an empowerment-based educational program and concluded that a higher self-efficacy perception positively influenced the ability of acceptance of illness and self-care. This was only possible through the implementation of an empowerment-based program, which promoted the knowledge about self-care and behaviors and, thus, encouraged autonomous and sensible decision-making. Sousa et al. (2017) conducted a research in Portugal and also found similar results, having alerted, though, to the fact that, at the beginning of the program, participants had difficulty in defining short- and long-term diabetes-related goals and purposes.

Because the interventions throughout this program aimed at supporting and helping patients to ponder on these aspects and to plan care according to the laid out objectives with the health team, these difficulties have been overcome, which allowed the participants to perceive an increased self-efficacy (Sousa et al., 2017).

It was found across the abovementioned studies that the obtained results not only proved that this care philosophy positively influences the self-efficacy perception of the participants, but also allows the health professional to provide care adapted to each patient's needs, thus contributing to higher gains in health. Therefore, this study emphasizes the need to adopt more person-centered care, consequently abandoning the traditional model, whose interventions are mostly based on more or less prescriptive counseling, so as to persuade the person with diabetes to follow the instructions according to the objectives of health professionals.

However, this study is not free from limitations, that may have affected the results. More specifically, a larger sample size was a limitation because this target population remains little amenable to the model change. From our perspective, this may be related to a weak awareness that the preservation of their health status depends on their involvement in the process and is not just in the hands of health professionals through prescriptive therapy. It is pertinent to add that there was a sample 
loss throughout the study, probably because it was implemented over several weeks, which may conflict with the life of patients. In future researches, it is advisable to increase the observing of the reasons of sample loss and to establish adequate schedules according to the availability of the participants.

It seems interesting, also in future studies, to implement this program in several health units that cover populations with different sociodemographic characteristics. Like the proposal made by other authors (Chen et al., 2015; Sousa et al., 2017), the authors of this study consider that it is necessary to carry out a follow-up to assess the long-term results of the program.

\section{Conclusion}

The participants of the Living Harmoniously with Diabetes program obtained a higher self-efficacy perception, meaning a greater capacity to set up objectives, define positive disease management strategies, and use resources, than the patients who did not participate in the educational program. It was concluded that the implementation of the program promoted the involvement of participants in the management of their health care and encouraged their decision-making and problem-solving skills, through searching and applying adaptive strategies. Therefore, the authors encourage the use of this kind of interventions, which can help the person to reflect on his/her goals, care, and resources, to integrate diabetes in his/her daily life, into his/her life project.

Further studies of this nature should be conducted to strengthen the effect of the program and to identify other variables likely to influence the studied phenomenon.

\section{References}

All European Academics. (2018). Código europeu de conduta para a integridade da investigação. Retrieved from https://www.allea.org/wp-content/uploads/2018/11/ ALLEA-European-Code-of-Conduct-for-Research-Integrity-2017-Digital_PT.pdf

American Diabetes Association. (2017). Standards of medical care in diabetes: 2017. The Journal of clinical and aplied research and education: Diabetes Care, 40(sup.1),
54-55. Retrieved from https://care.diabetesjournals. org/content/diacare/suppl/2016/12/15/40.Supplement_1.DC1/DC_40_S1_final.pdf

Anderson, B., \& Funnel, M. (2005). The art of empowerment: Stories and Strategies for Diabetes Educators (2a nd.). Alexandria, EUA: American Diabetes Association.

Anderson R., Fitzgerald J., Gruppen L., \& Funnell, M. (2003). The diabetes empowerment scale-short form. Diabetes Care, 26(5),1641-1642. doi:10.2337/diacare.26.5.1641-a

Associaçáo Protetora dos Diabéticos de Portugal. (2017). $A B C$ da Diabetes. Retrieved from https://apdp.pt/ diabetes/abc-da-diabetes/

Aveiro, M., Santiago, L., Pereira, P., \& Simóes, J. (2015). Estudo de fiabilidade da escala de capacidade de controlo da diabetes: Versão breve. Acta Medica Portuguesa, 28(2), 177-181. Retrieved from https://ubibliorum.ubi.pt/bitstream/10400.6/4860/1/Aveiro\%2c\%20M.\%20et\%20 al. $\% 202015 . \% 20$ Estudo $\% 20$ de $\% 20$ Fiabilidade $\% 20$ da $\% 20$ Escala $\% 20$ de $\% 20$ Capacidade $\% 20$ de $\% 20$ Controlo\%20da\%20diabetes.pdf

Bandura, A. (1989). Human agency in social cognitive theory. American Psycologist, 44(9), 1175 1184. Retrieved from https://pdfs.semanticscholar. org/7539/60aef3f2747f757d73bc5c9330a21b484f2e.pdf

Brunton, S., \& Polonsky, W. (2017). Medication adherence in type 2 diabetes mellitus: Real-world strategies for addressing a common problem. The Journal of Family Practice, 66(4), 546-549. doi:10.2147/PPA.S106821

Chen, F., Wang, H., Lin C., Hsu, Y., \& Chen, W. (2015). Efficacy of an empowerment program for Taiwanese patients with type 2 diabetes: A randomized controlled trial. Applied Nursing Research, 28(4), 366-373. doi:10.1016/j.apnr.2014.12.006

Cortez, D., Macedo, M., Souza, D., Santos, J., Afonso, G., Reis, I. \& Torres, H. (2017). Evaluating the effectiveness of an enpowerment program for serlf-care in type 2 diabetes: A cluster randomized trial. $B M C$ Public Health, 17 (41), 1-10. doi:10.1186/s12889016-3937-5

Direção-Geral da Saúde. (2017). Programa nacional para a diabetes: 2017. Lisboa, Portugal: Author. Retrieved from https://www.dgs.pt/portal-da-estatistica-da-saude/diretorio-de-informacao/diretorio-de-informacao/por-serie-894111-pdf.aspx?v=11736b14-73e6-4b34-a8e8-d22502108547

Funnel, M., Tang, T., \& Anderson, R. (2007). From DSME to DSMS: Developing empowerment-based diabetes self-management support. Diabetes Spectrum, 20(4), 221-226. doi:10.2337/diaspect.20.4.221

Internacional Diabetes Federation. (2017). Diabetes atlas (8a ed.). Brussels, Belgium: Author. 
Menino, E., Dixe, A., \& Louro, M. (2016). Construção e validação da escala de educação terapêutica para o comportamento de autocuidado na diabetes. Revista de Enfermagem Referência, 4(8), 35-44. doi:10.12707/ RIV15049

Observatório da Diabetes. (2016). Diabetes: Factos e Números - O Ano de 2015 - Relatório Anual do Observatório Nacional da Diabetes. Lisboa, Portugal: Sociedade Portuguesa de Diabetologia.

Ratner, N., Davis, E., Lhorka, L., Wille S., \& Walls, M. (2017). Patient-centered care, diabetes empowerment, and type 2 diabetes medication adherence among american indian patients. Clinical Diabetes, 35(5), 281-285. doi:10.2337/cd17-0008
Regulamento n. ${ }^{\circ}$ 798/2018. (2018). Diário da República n. ${ }^{\circ}$ 231/2018 - Série II. Comissão Nacional de Proteção de Dados. Lisboa, Portugal.

Saad, A., Younes, H., Ahmed, H., Brown, A., Alowesie, M., \& Hassoun, K. (2017). Self-efficacy, self-care and glycemic control in Saudi Arabian patients with type 2 diabetes mellitus: A cross-sectional survey. Diabetes Research and Clinical Practice, 137, 28-36. doi:10.1016/j.diabres.2017.12.014

Sousa, M. R., Pereira, F., Martins,T., Rua, I., Ribeiro, I., Cerdeira, C., ... Santos, C. (2017). Impact of an educational programme in Portuguese people with diabetes. Action Research, 27(2), 1-19. doi:10.1177/1476750317736369 
